\title{
LIMITATION OF RELIGIOUS FREEDOM IN RESPONSE TO COVID-19: FROM PUBLIC HEALTH REGULATIONS TO DISCRIMINATORY POLICIES
}

\author{
${ }^{1}$ Hanif Nur Widhiyanti, ${ }^{2}$ Anak Agung Ayu Nanda Saraswati \\ ${ }^{1}$ Faculty of Law Universitas Brawijaya, hanif.nur@ub.ac.id \\ ${ }^{2}$ Faculty of Law Universitas Brawijaya, anandasaraswati@ub.ac.id
}

\begin{abstract}
A number of regulations and policies implemented by some countries regarding the limitations of freedom to manifest religion or belief have been highly debated since the Covid-19 pandemic. Many argue such policies are discriminative and inconsistent with human rights law. Thus, this paper aims at analyzing the concept of human rights in the implementation of religion manifestation during the pandemic, and investigating how states implement policies according to the international human rights legal framework. This normative research which uses comparative and conceptual approach concludes that policies established by states in general can be legitimized on several conditions, among others for public health concerns. In addition, the proportionality and the nondiscrimination principles need to be applied accordingly.
\end{abstract}

Keywords: Freedom of Religion; Human Rights; Covid-19 Pandemic; Discrimination Policies; Public Health

\section{Introduction}

The implementation of freedom to practice (manifest) religion or belief has been facing challenges around the world since the beginning of $2020^{1}$, when the World Health Organization (WHO) declared the outbreak of COVID-19 pandemic ${ }^{2}$. Taking into concern of the alarming degree of the spread as well as the severity of the virus, WHO has urged governments to take all necessary actions to prevent and stop the spread of the deadly virus ${ }^{3}$. Since then, various policies have been established and implemented by the governments to control the spread of the disease first identified in Wuhan, China ${ }^{4}$. Such policies, which have impacted almost if not everyone

1 Paul Marshal, "Do Government Limitations on Larger Church Gathering Violate Religious Freedom?," last modified 2020, accessed March 15, 2021, https://providencemag.com/2020/03/government-limitations-largerchurch-gathering-violate-religious-freedom/; Georgia Alida Du Plessis, "COVID-19 and Limitations to the International Right to Freedom of Religion or Belief," Journal of Church and State csaa082 (2020); Mark Hill QC, "Coronavirus and the Curtailment of Religious Liberty," MDPI, Open Access Journal 9, no. 4 (2020): 1-19.

2 World Health Organization, "WHO Director-General's Opening Remarks at the Media Briefing on COVID-19," last modified 2020, accessed February 15, 2021, https://www.who.int/director-general/speeches/detail/whodirector-general-s-opening-remarks-at-the-media-briefing-on-covid-19---11-march-2020.

3 Human Rights Watch, "Human Rights Dimensions of COVID 19 Response," last modified 2020, accessed February 16, 2021, https://www.hrw.org/news/2020/03/19/human-rights-dimensions-covid-19-response.

4 Serdar Bitmez, "Saudi Arabia Bans Locals from Umrah over Coronavrius," last modified 2020, accessed February 25, 2021, https://www.aa.com.tr/en/middle-east/saudi-arabia-bans-locals-from-umrah-overcoronavirus/1754648; Martin Chulov, "Saudi Arabia Closes Two Holiest Shrines to Foreigners as Corovirus Fears Grow," last modified 2020, accessed February 25, 2021, https:/www.theguardian.com/world/2020/feb/27/saudi-arabia-coronavirus-shrines-pilgrims-haij-bans; Afkar Abdullah, "Coronavirus in UAE: Friday Prayers at Mosques Restricted to 15 Munites, Gathering at Churches 
around the world, frequently include programs involving the public mass and limitations on several human rights such as the freedom of movement. One aspect that continues to be highlighted in relation to COVID-19 is the limitation on the right to practice religion in public ${ }^{5}$.

Both central and local governments in various countries have developed and are still implementing policies restricting the right to publicly practice religion to respond to the global health crisis. Generally, states have prohibited religious activities carried out in large gatherings, and some even have completely closed their places of worship within a certain period of time ${ }^{6}$. Indeed, all of these limitations are not lacking of controversy. While most people agree upon the purposes of the limitations, some oppose by putting forward the view that among other things, religious activities are as important as access to basic needs, and that attending a religious service is no more risky than visiting a shopping place. Efforts to cover the spread of the virus even becomes more challenging through the counterproductive behavior shown by several religious groups ${ }^{7}$, where many of them still hold and plan to hold meetings that involve large numbers of people. This has then raised the debate on whether limitations imposed by states are considered violating religious freedom or are considered legally valid as a form of government's responsibility to protect its citizens. The main question is whether or not a country can limit freedom of religion in response to tackle COVID-19? If so, how far? It should be noted that religious congregations are essential occasions for people to exercise and share their thoughts and beliefs, but they are also venues for the transmission of the virus, which not only harms those who attend the meetings but also everyone they interact with. This crisis has risen the need of government to act decisively without violating individual freedoms or targeting marginal groups even after the crisis has passed.

Suspended," last modified 2020, accessed February 25, 2021, https://www.khaleejtimes.com/coronavirusoutbreak/coronavirus-in-uae-friday-prayers-at-mosques-restricted-to-15-minutes-gatherings-at-churchessuspended; Gayle Manchin, "COVID-19 Symposium: Don't Let Religious Freedom Become a Casuality of Coronavirus, Opinio Juris," last modified 2020, accessed February 25, 2021, https://opiniojuris.org/2020/04/06/covid-19-symposium-dont-let-religious-freedom-become-a-casualty-ofcoronavirus/; Alexis Artaud de La Ferriere, "Coronavirus: How New Restrictions on Religious Liberty Vary Across Europe," last modified 2020, accessed February 25, 2021, https://theconversation.com/coronavirus-hownew-restrictions-on-religious-liberty-vary-across-europe-135879.

5 Eugene Yapp, "Covid-19 and the Right to Freedom of Religion and Belief," last modified 2020, accessed February 27, 2021, http://shapesea.com/op-ed/covid-19/covid-19-and-the-right-to-freedom-of-religion-andbelief/.

6 de La Ferriere, "Coronavirus: How New Restrictions on Religious Liberty Vary Across Europe."

7 Simon Dein et al., "COVID-19, Mental Health And Religion: An Agenda For Future Research," Mental Health,

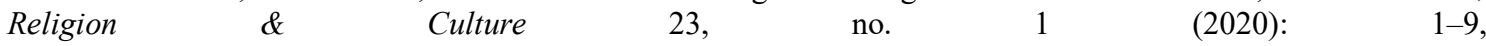
https://www.tandfonline.com/doi/pdf/10.1080/13674676.2020.1768725?needAccess=true. 
For this reason, a conceptual legal framework related to fulfilling the right to carry out religious activities in times of pandemic with a human rights approach becomes crucial. This is important to find the essence of freedom to manifest religion that can be universally implemented so as to be able to formulate how to carry out religious activities during the pandemic with a human rights approach. Thus, this paper focuses on two issues, namely the ability of states to limit the freedom to practice religion or belief during the pandemic under the human rights legal framework, and the extent to which state's policies related to religious freedom in responding to the spread of COVID-19 are in accordance with a human rights approach.

\section{Methods}

This research is a normative study, which is a scientific research procedure based on the logic of legal science from the normative perspective with a focus on the application of the positive law ${ }^{8}$. In addition, the statute approach was used to understand the philosophical content of national and international regulations and to analyze whether there is a philosophical clash between these regulations and related issues ${ }^{9}$. A conceptual approach was also used to analyze views and legal doctrines to produce law, legal concepts and principles to build a legal argumentation. The legal materials were collected through library research ${ }^{10}$, from laws, books, journals, scientific essays and research reports, all of which were descriptively and qualitatively analyzed. This study aims to complement old theories or compile new theories based on secondary data as the main source ${ }^{11}$.

\section{Results and Discussion}

\subsection{Legality of Limitation of Religious Freedom}

As a fundamental and universal human right, freedom of religion or belief often triggers prolonged disputes among the international community, including states. This is due to the scope of the freedom itself which has two dimensions, namely the forum internum and forum externum 12

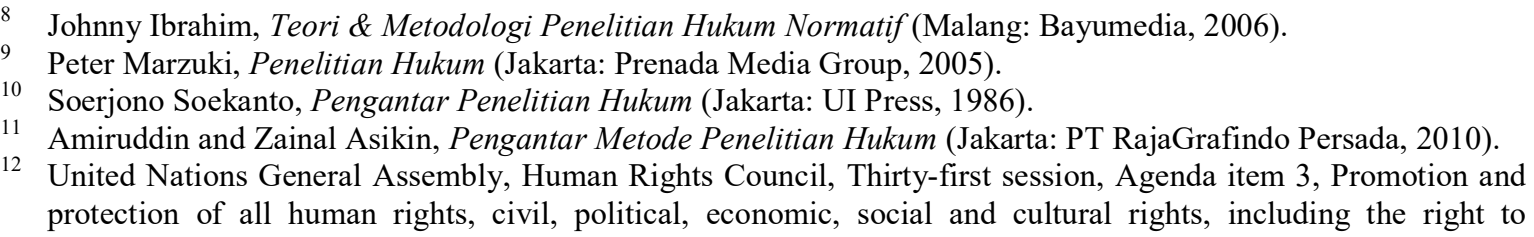
protection of all human rights, civil, political, economic, social and cultural rights, including the right to 
Forum internum is the right to own and hold an inner belief ${ }^{13}$, often called freedom of thought, conscience and religion. This forum has absolute protection ${ }^{14}$, meaning that no situation can ever justify the violation of the freedom for whatever reason, including state emergency or even national security reasons. This right includes adhering to a certain religion or belief based on one's own choice, carrying out a religious interpretation and having the right to convert. Although controversial in various countries, this aspect also allows for the right to reject or change religion and the right not to be forced to believe in something. In addition, legislative provisions that establish boundaries in this domain is inconsistent with the requirements of internal freedom ${ }^{15}$.

On the other hand, forum external includes the right to carry out, manifest or externally present a religion or belief, either conducted alone or in public as part of a group or community, through teaching, worship, practice, and other forms of obedience. This includes the right to share and spread religious teachings, encourage others to adopt the same views and dogmas ${ }^{16}$, publish and distribute religious literature and other forms of information, own and use buildings for worship and express religion or belief through clothing, rituals and symbols. This aspect can be limited only in the very restricted circumstances specified in the restriction clause that applies.

These two concepts, forum internum and forum externum, have in fact been stipulated in various human rights instruments in the international level. The UDHR for example, regulates that everyone has the right to freedom of thought, conscience and religion. Meanwhile, the ICCPR, one of the main international human rights treaty with 173 states parties (as of November 2020), also recognize such right and suggest that no limitations are allowed on the right to believe (or not to believe) in another religion or belief, an opinion generally known as

development, Report of the Special Rapporteur on freedom of religion or belief, A/HRC/31/18. See also: Malcolm Evans, "The Freedom of Religion or Belief in the European Court of Human Rights since the Kokkinakis Case Or 'Quoting Kokkinakis,'” in The European Court of Human Rights and the Freedom of Religion or Belief (Boston: Brill Nijhoff, 2019), 33-54; Peter Petkoff, "Forum Internum and Forum Externum in Canon Law and Public International Law with a Particular Reference to the Jurisprudence of the European Court of Human Rights," Religion and Human Rights 7, no. 3 (2012): 183-214.

13 Katayoun Alidadi, "Reasonable Accommodations for Religion and Belief: Adding Value to Article 9 ECHR and the European Union's Anti-Discrimination Approach to Employment?," European Law Review 37, no. 6 (2012): $693-715$.

14 Jeroen Temperman, “Are State Churches Contrary to International Law?," Oxford Journal of Law and Religion 2, no. 1 (2013): 119-149.

15 European Commission For Democracy Through Law, "Guidelines For Legislative Reviews of Laws Affecting Religion Or Belief OSCE/ODIHR Panel Of Experts On Religion Or Belief," last modified 2004, accessed February 27, 2021, https:/www.venice.coe.int/webforms/documents/default.aspx?pdffile=CDL(2004)061-e.

16 United Nations Human Rights Office of the High Commissioner, "International Standards on Freedom of Religion or Belief,” accessed $\quad$ March https://www.ohchr.org/EN/Issues/FreedomReligion/Pages/Standards.aspx. 
forum internum. Article 18 Paragraph (3) of ICCPR further states that the government cannot limit the manifestations of freedom of religion or belief unless such limits are (1) determined by law; (2) subject to a legitimate purpose; and (3) necessary to achieve the goal.

First, the limitation must be prescribed by law ${ }^{17}$, meaning that is must be clearly regulated in writing in a product of national law ${ }^{18}$. The restriction must be clear and accessible to all, declared openly to the public as a form of transparency and accountability, accompanied by reasons and recovery mechanisms so that progressive realization efforts can continue even though at a minimal level. These requirements have a qualitative element in the sense that the law must acknowledge the non-retroactive principle, and its enforcement should not be carried out arbitrarily ${ }^{19}$. Second, the limitation must be necessary. International jurisprudence suggests that a limitation is deemed necessary if it has a legitimate and reasonable aim, meaning that the restriction is neutral and proportional, and there is a rational and realistic proportional connection between the means used and the objectives to be realized ${ }^{20}$. The level of emergency is a tool to determine the purpose and method used. So it strives to be less restrictive. Furthermore, the principle of proportionality must be appreciated not only in the laws that frame boundaries, but also by system applying the law. In a democratic society, the limitations imposed must not destroy the functioning democracy in society. Third, the limitation must have a legal basis or legitimate aim, namely to protect public safety or order, health or morality, or the essential rights of others. In addition to the three requirements, the limitation must also not be discriminative ${ }^{21}$ whether against certain groups or in the discriminatory methods. State action must be neutral and impartial.

17 Cole Durham, "Freedom of Religion or Belief: Law Affecting the Structuring of Religious Communities" (Organization for Security and Co-operation in Europe, https://www.osce.org/files/f/documents/4/7/16698.html.

18 Carolyn Evans, Legal Protection of Religious Freedom in Australia (Australia: Federation Press, 2012).

19 Cole Durham Jnr, "Religious Freedom in a Worldwide Setting: Comparative Reflections," in Speech Delivered at Political Academy of Social Sciences (Brigham University, 2011).

20 Jim Murdoch, Protecting the Right to Freedom of Thought, Conscience and Religion under the European Convention on Human Rights (Strasbourg: Council of Europe, 2012), https://www.echr.coe.int/LibraryDocs/Murdoch2012_EN.pdf; Parliament of Australia, "Definition and Scope of the Right to Freedom of Religion or Belief," last modified 2019, accessed February 27, 2021, https://www.aph.gov.au/Parliamentary_Business/Committees/Joint/Foreign_Affairs_Defence_and_Trade/Freedo mofreligion/Interim_Report/section? $\mathrm{id}=$ committees\%2Freportjnt $\% 2 \mathrm{~F} 024110 \% 2 \mathrm{~F} 25177 \#: \sim: \overline{t e x t}=\overline{\text { Religious }}$ freedom includes both the,be limited for any reason.\&tex.

21 Human Rights Council, Thirty-seventh session, 26 February-23 March 2018, Agenda item 3, Promotion and protection of all human rights, civil political, economic, social and cultural rights, including the right to development, Report of the Special Rapporteur on freedom of religion and belief, A/HRC/37/49. See also: Gillian MacNaughton, "Untangling Equality and Non-Discrimination to Promote the Right to Health Care for All," Health and Human Rights Journal 11, no. 2 (2009): 47-63. 


\subsection{Human Rights Conception on the Limitation of Freedom of Religion on the Grounds of Public Health during the COVID-19 Pandemic}

It is commonly known that the tension between public health and the right to individual freedoms such as freedom of religion is nothing new. Somewhere between the religious rights of individual and the public health objectives lies a lawfully feasible balance ${ }^{22}$. One example is the debate about vaccination as a public health achievement, where there is involvement of religion or belief that affects a person's decision to get vaccinated. In some countries, what is needed to free a child from the vaccinations required to attend school is a statement from the parents that the vaccination violates their religious beliefs ${ }^{23}$. However, in the midst of the COVID-19 crisis, there is a political process that may turn the right to freedom of religion into a threat to public health.

In the context of the pandemic, the right to life is most obviously affected by the virus, which until today has taken thousands of lives all over the world. On this matter, each country has an obligation to prevent people from deprivation of life ${ }^{24}$, an obligation known as the due diligence. This obligation comprises the protection of individuals from threats to life posed by others carrying a certain disease. Thus, various limitations including religious freedom limitations are deemed necessary to protect the legitimate interests of the state, by preventing the spread of COVID-19 as an emergency. Regarding this issue, the Siracusa Principles regarding the provisions of limitations and derogations in the ICCPR contain guidance that address the validity of these limitations ${ }^{25}$. Based on the Principles, public health is an effort related to a severe danger to public health or person who is a member of a community. The policy of restriction must be explicitly intended to avoid disease or to offer care for those who are sick. Thus, in the face of the global COVID-19 pandemic, state limitations on large public gatherings and freedom of movement driven by serious public health concerns can actually be justified on

22 Gordana Pelčić, Silvana Karačić, and Galina L Mikirtichan, "Religious Exception for Vaccination or Religious Excuses for Avoiding Vaccination," Croat Med J. $57 \quad$ (2016): 516-521, https://www.ncbi.nlm.nih.gov/pmc/articles/ PMC5141457/pdf/CroatMedJ_57_0516.pdf.

23 Roland Pierik, "On Religious and Secular Exemptions: A Case Study of Childhood Vaccination Waivers," $\begin{array}{lllll}\text { Ethnicities. } & 17, & 2 & \text { (2017): } & \text { 2020-241, }\end{array}$ https://www.ncbi.nlm.nih.gov/pmc/articles/PMC5428064/pdf/10.1177_1468796817692629.pdf.

24 UN Human Rights Committee, International Covenant on Civil and Political Rights, 2018.

25 Siracusa Principles on the Limitation and Derogation of Provisions in the International Covenant on Civil and Political Rights Annex, UN Doc E/CN.4/1984/4 (1984). See also: Roojin Habibi, Steven J. Hoffman, and Gian Luca Burci, "The Stellenbosch Consensus on Legal National Responses to Public Health Risks, Clarifying Article 43 of the International Health Regulations," International Organizations Law Review (2020): 1-68, https://brill.com/view/journals/iolr/aop/article-10.1163-15723747-2020023/article-10.1163-15723747-

2020023.xml?language $=$ en. 
the basis of protecting public health. Any actions should be precisely directed at avoiding illness or injury of the sick and injured. In this connection, the international health regulations from the World Health Organization must be adopted. This means that limitations on religious freedom with the aim of protecting public health must fulfil these 3 conditions, namely (1) there is a severe risk to the health of the members of a society, (2) it is intended to prevent a disease or injury or to give care for the sick and injured, and (3) the limitation uses global health rules and guidelines from the World Health Organization.

Furthermore, states are required to reveal that preventive actions are necessary to control and limit the spread of transferrable virus in order to finally improve the health, rights and freedoms of individuals ${ }^{26}$. If the original reason for imposing a restriction no longer applies, the restriction shall be lifted without delay. In addition, liability instruments must be in place to enable affected individuals to challenge the relevance of these limitations. Failure to comply with these safeguards not only risks the most vulnerable of various human rights violations but also ultimately undermines larger public health goals. For this reason, in cases where states impose public health measures that may limit certain rights, they must still fulfill the core human rights standards. For example, states should ensure that the basic needs of the community such as food, water, sanitation and shelter are met. Likewise, those who experience economic losses as a result of public health measures are to be given fair compensation ${ }^{27}$. More importantly, all these actions must be corrected and reviewed. States should also analyze and discuss the situation even after the crisis to guarantee that public health action is evidence-based, needed, and balanced to open knowledge and science, health issues, and human rights rules and standards.

Based on the above analysis, state' interferences with fundamental human rights must be observed with cautiousness. Any form of intervention must be materially and temporally limited, according to the requirements needed to address the pandemic. Moreover, it is undeniable that such limitation must not be used in a discriminatory manner which may result in the suppression of dissent or the persecution of minorities. Therefore, in applying measures on the limitation of

26 United Nations Economic and Social Council, "The Right to the Highest Attainable Standard of Health (Article 12 of the International Covenant on Economic, Social and Cultural Rights)," last modified 2020, accessed March 10, 2021,
21/ https://tbinternet.ohchr.org/_layouts/15/treatybodyexternal/Download.aspx?symbolno=E/C.12/2000/4\&Lang=en

27 World Health Organization, "Chapter 10: Controlling the Spread of Infectious Diseases, Advancing the Rights to Health: The Vital Role of Law," last modified 2016, accessed March 15, 2021, https://www.who.int/healthsystems/topics/health-law/chapter 10. pdf? ua=1. 
freedom of religion in response to COVID-19, state' policies must have a time limit and avoid closing places of worship in a discriminatory manner.

\subsection{Practices of States: Discriminative Policies}

The international human rights legal framework regulates that in determining and applying limitations, states must not have discriminatory aims or employ discriminatory methods. In this case, the preconditions for state action must be neutral and impartial. State' response to suppressing transmission efforts have occurred in various ways. Thus, it is necessary to remember that all forms of intervention against religious communities should not make discrimination against one person or religious group. In practice, however, public health measures recently taken by governments in response to containing and limiting the spread of the novel Coronavirus have impacted different minority groups in different ways. In this regard, several countries are under the spotlight because their governments are considered to have failed to protect certain vulnerable religious communities. Concerns are also based on a number of reports from religious minority groups from around the world who are facing discrimination due to this pandemic ${ }^{28}$. This raises a discourse on the legality of imposing limitations in dealing with COVID-19. Many are in the opinion that the limitations are a form of human rights violations and, in several cases, are an outright repression of religious groups and minorities.

As the first example is the government officials of Iran who are now accused of deliberately putting religious minorities at risk. USCIRF has reported that Iran has sent many religious minorities to jail. Following this, some protestors have stated concern on the lack of adequate protections by the custodial authorities to reduce the spread of the virus, which has emerged in Evin, Urmia and Ghazal Hesar prisons ${ }^{29}$. Despite the fact that in the early March of 2020, Iran declared it would release 54,000 prisoners who were on leave ${ }^{30}$, a number of Sufi inmates in Great Tehran Prison were allegedly transferred to wards with identified cases of COVID-19. In addition, other Sufis in Ghazal Hesar Prison were transferred to the overloaded

28 Jianhua $\mathrm{Xu}$, Guyu Sun, and Wei Cao, "Stigma, Discrimination, and Hate Crimes in Chinese-Speaking World amid Covid-19 Pandemic," Asian Journal of Criminology $16 \quad$ (2021): 51-74, https://link.springer.com/content/pdf/10.1007/s11417-020-09339-8.pdf.

29 Center of Human Rights in Iran, “Coronavirus: Citing Crowded Prisons, Renowned Attorney Nasrin Sotoudeh's Husband Calls for Release of Political Prisoners," last modified 2020, accessed March 1, 2021, https://iranhumanrights.org/2020/02/coronavirus-citing-overcrowded-prisons-renowned-attorney-nasrinsotoudehs-husband-calls-for-release-of-political-prisoners/.

30 Michael R. Pompeo, "United States Calls for Humanitarian Release of All Wrongfully Detained Americans in Iran, Press Statement," last modified 2020, accessed March 1, 2021, https://www.state.gov/united-states-callsfor-humanitarian-release-of-all-wrongfully-detained-americans-in-iran/. 
wards of the prison where they are at bigger risk to be contracted to the virus. This makes government officials in Iran are now charged with intentionally putting religious minorities at risk.

Likewise, in China, activists are afraid that the response by the government jeopardizes the violations of freedom of religion. As reported by USCIRF in its Annual Report of $2019^{31}$, since April 2017, the Chinese regime has imprisoned up to 1 million Uighurs and other Muslims in concentration camps in Xinjiang. Additionally, reports also highlighted the authorities who have forced Uighurs to work in factories across the country to compensate for the drop in the production during the quarantine. Furthermore, in the beginning of 2020, millions of people across Xinjiang were quarantined without warnings by authorities. Reports even stated that Uighurs in Ghulja city had very restricted access to food and officers also asked for payment to bring supplies ${ }^{32}$.

Moreover, in South Korea, a religious group known as the Shincheonji Church has reported over 4,000 cases of discrimination against its congregation since the virus has emerged, such as layoffs, workplace bullying, domestic abuse, stigma and slander ${ }^{33}$. The church is also currently facing a lawsuit from the local government because it is considered the main cause of the spread of COVID-19 in South Korea. Furthermore, in Indonesia, the Tasikmalaya Regency Government was considered taking advantage of the COVID-19 situation by closing down or sealing the Al-Aqsa mosque belonging to the Indonesian Ahmadiyah Congregation (JAI). Thus, the government is asked to protect the rights of all residents of Tasikmalaya, in this case the Ahmadiyya congregation from actions that have the potential to violate or reduce the rights of the members of the Ahmadiyya Community ${ }^{34}$. The Interfaith Network (Jakatarub) has further requested the revocation of the West Java Governor Regulation No.12 of 2011 which is often

31 United States Commission on International Religious Freedom, USCIRF Recommended Countries of Particular Concern, China, Annual Report, 2019.

32 Shohret Hoshur, "Residents of Xinjiang's Ghulja City Going Hungry Under Coronavirus Quarantine," last modified 2020, accessed March 1, 2021, https:/www.rfa.org/english/news/uyghur/hungry02242020153509.html.

33 Raphael Rashid, "Being Called a Cult Is One Thing, Being Blamed for an Epidemic Is Quite Another," last modified 2020, accessed March 1, 2021, https:/www.nytimes.com/2020/03/09/opinion/coronavirus-southkorea-church.html; Anonimous, "0228 Letter of Appeal from Shincheonji Church of Jesus in Regards to COVID-19," last modified 2020, accessed March 1, 2021, http://enblog.shincheonji.kr/2020/03/0228-letter-ofappeal-from-shincheonji.html.

34 ELSAM, "Bupati Tasikmalaya Harus Lindungi Jamaah Ahmadiyah: Hentikan Penyegelan Mesjid, Dan Fokus Tangani Wabah Covid-19," last modified 2020, accessed March 1, 2021, https://elsam.or.id/bupati-tasikmalayaharus-lindungi-jamaah-ahmadiyah-hentikan-penyegelan-mesjid-dan-fokus-tangani-wabah-covid-19/. 
used as a reference by the Regional Government in committing discriminatory actions against Indonesian citizens who are members of the Ahmadiyya Community.

Discrimination against members of religious minorities is also conducted by some governments by eliminating the religious minorities from agendas designed at supporting the victims of COVID-19, or by giving less support than is offered to those belonging to the majority groups. For example, hospitals in India are suspected of providing different care for Hindu and Muslim patients ${ }^{35}$. Various sources have reported that the hospital provides lower quality to Muslim patients. In Gujarat state, for example, a public hospital has placed Hindu and Muslim COVID-19 patients in separate wards, triggering accusations of apartheid ${ }^{36}$. In addition, officers in Pakistan have accused Shia Muslims from the ethnic Hazara ethnic minority for the spread of the virus. Likewise, a local Muslim charity has been accused of refusing to distribute ration goods to Christians who live in the same location as Muslims ${ }^{37}$. As a further illustration, in some areas of Pakistan, the authorities have also been reported to refuse to provide food assistance to Hindus and Christians, claiming that the aid is only provided for Muslims. This discrimination is exacerbated by attempts to convert Christians and Hindus who are told that they will only receive rations if they are to recite the Kalma and then convert.

Added to the list is the government in Buddhist-majority in Sri Lanka which declared the decision on the burial practices of Muslim minorities by forcing cremations for victims of COVID-19. Although WHO and Ministry of Health guidelines have stated that burial of the bodies of those who have died from COVID-19 are acceptable, Sri Lankan officials continue to cremate the bodies of two Muslims who died from the disease ${ }^{38}$. Scholars and citizens have expressed concern over the complete disregard for cultural and religious sensitivities in the actions of these officials and who demand that burials should be allowed for Muslims ${ }^{39}$. This type of burial practices of the victims of COVID-19 are also questioned in Iraq. An authoritative

35 The National News, "Indian Hospitals Shuns Muslims as Coronavirus Spurs Discrimination," last modified 2020, accessed March 1, 2021, https:/www.thenationalnews.com/world/asia/indian-hospital-shuns-muslims-ascoronavirus-spurs-discrimination-1.1008876.

36 (Aljazeera 2020)

37 The U.S. Commission on International Religious Freedom, "USCIRF Troubled by Denial of Food Aid to Pakistani Hindus and Christians," last modified 2020, accessed March 5, 2021, https://www.uscirf.gov/newsroom/releases-statements/uscirf-troubled-denial-food-aid-pakistani-hindus-and-christians.

38 Shereena Qazi and Ashkar Thasleem, "Anguish as Sri Lanka Forces Muslims to Cremate COVID-19 Victims," last modified 2020, accessed March 5, 2021, https://www.aljazeera.com/news/2020/04/anguish-sri-lanka-forcesmuslims-cremate-covid-19-victims 200403053706048.html.

39 Aljazeera, "Sri Lanka: Muslims Face Extra Threat as Coronavirus Stirs Hate," last modified 2020, accessed March 5, 2021, https://www.aljazeera.com/news/2020/05/11/sri-lanka-muslims-face-extra-threat-as-coronavirusstirs-hate/. 
religious figure intervened with a fatwa and acknowledged that the dead must be covered in three shrouds and be buried, as required in Islam as cremation is forbidden in Islam ${ }^{40}$. It has also been reported that in developed countries such as the United States as well as the United Kingdom, a disproportionate number of ethnic minorities have contracted COVID-19, subsequently being an indication of the social inequalities present within such countries and raising questions about what the governments should do to address such issues.

In countries such as Turkey and South Korea, religious minorities have faced the brunt of religious discrimination and hate speech by the majority community with the former being labeled as 'carriers' of the virus. Therefore in response to hate speech, the governments must immediately address any surge in religious hate speech and ethno-religious discrimination, while embassies are urged to monitor any increase in this phenomenon and to raise concerns with the governments if the issue is left unaddressed. Furthermore, state policies and measures taken to respond to COVID-19 must not be used as a validation to silence, target, or harass any members of civil society, including those who are human rights defenders, journalists, and media workers. States must highlight their responsibility to respect and protect human rights even in the times of national crisis and encourage active efforts to control the pandemic.

From several policies implemented in a number of countries, it can be concluded that restrictive practices that lead to acts of discrimination can be in various forms. They include but not limited to the transfer of certain religious groups or minorities to overcrowded wards, limited access to medical or food towards certain religious groups or minorities, coercion given to certain religious groups or minorities to work harder than the majority groups or other groups, termination of employment, oppression at work, domestic abuse, stigma and slander against religious or minority group, the closure of places of worship for minority religious groups, exclusion of religious or minority groups from programs aimed at helping victims of COVID-19, and forced burials that are not in accordance with religious teachings. Therefore, states need to evaluate their discriminative laws and regulations that are incompatible with human rights principles. Moreover, despite the fact that such polices are prescribed by law and serve as a legitimate aim, states need to ensure that the practice of the laws and policies are conducted in a non-discriminatory matter.

40 Brookings, “Are Covid-19 Limitations Inflaming Religious Tensions?,” last modified 2020, accessed March 7 , 2021, https://www.brookings.edu/blog/order-from-chaos/2020/04/13/are-covid-19-limitations-inflamingreligious-tensions/. 


\section{Conclusions}

It is concluded that various limitation on the practice of religion in the name of tackling the spread of the global pandemic could be justified by international human rights laws and principles. During times of emergency like today, states may impose necessary regulations or policies to protect legitimate interests, in this case public safety and health. However, it must be noted that although freedom of religion can be limited on public health grounds, these limitations must be proven to be necessary, proportionate and able to be implemented in a nondiscriminatory manner. Any form of intervention related to COVID-19 should be applied temporarily and lifted as soon as they are no longer necessary to protect public health from the threat of the virus.

While in theory, countries are expected to remain dedicated in maintaining a human rightsbased approach to manage this pandemic and to facilitate the emergence of healthy societies in conformity with the rule of law through the protection of human rights, however, in practice, containment measures adopted by several states imply severe interventions with a number of human rights, including but not limited to the right to manifest one's belief or religion. As far as this pandemic continues, there are indeed a number of countries that are under the spotlight because their policies are considered discriminatory and not in accordance with the international human rights standards. From several policies implemented in various countries, it can be concluded that restrictive practices that lead to acts of discrimination can be in the form but not limited to the transfer of certain people from religious groups or minorities to overloaded wards, limited access to medical help and food for certain religious groups, coercion given to certain religious groups or minorities to work harder than others, termination of employment, bullying at work, domestic abuse, stigma and slander against religious or minority groups, closure of places of worship of religious minorities, exclusion of religious groups or minorities from programs that aim to help victims of COVID-19, and forced burials that are not in accordance with the religious teachings.

Moreover, it is believed that COVID-19 will not be the last pandemic experienced by the human race, so the understanding towards how to respect, protect, and fulfill human rights during outbreaks and other public health crises becomes vital not only to guarantee that states effectively address public health issues, but also to protect people's equality and inherent dignity. Thus, it is highly expected that every government can take active measures to guarantee that individuals in religious and minority faith groups are safe and protected as well as receive 
adequate health services in a fair and non-discriminatory manner. It is also imperative for states to establish active communication strategies and networks to provide information that is precise, accessible, transparent and reliable to the wider public including to members of religious minority and faith communities.

\section{Acknowledgement}

This research was granted by the Tematik Research Grant Program at Universitas Brawijaya in 2020.

\section{References}

Abdullah, Afkar. "Coronavirus in UAE: Friday Prayers at Mosques Restricted to 15 Munites, Gathering at Churches Suspended." Last modified 2020. Accessed February 25, 2021. https://www.khaleejtimes.com/coronavirus-outbreak/coronavirus-in-uae-friday-prayers-atmosques-restricted-to-15-minutes-gatherings-at-churches-suspended.

Alidadi, Katayoun. "Reasonable Accommodations for Religion and Belief: Adding Value to Article 9 ECHR and the European Union's Anti-Discrimination Approach to Employment?” European Law Review 37, no. 6 (2012): 693-715.

Aljazeera. "India Hospital Segregates Muslim and Hindu Coronavirus Patients." Last modified 2020. Accessed March 5, 2021. https://www.aljazeera.com/news/2020/4/16/india-hospitalsegregates-muslim-and-hindu-coronavirus-patients.

- "Sri Lanka: Muslims Face Extra Threat as Coronavirus Stirs Hate.” Last modified 2020. Accessed March 5, 2021. https://www.aljazeera.com/news/2020/05/11/sri-lanka-muslimsface-extra-threat-as-coronavirus-stirs-hate/.

Amiruddin, and Zainal Asikin. Pengantar Metode Penelitian Hukum. Jakarta: PT RajaGrafindo Persada, 2010.

Anonimous. "0228 Letter of Appeal from Shincheonji Church of Jesus in Regards to COVID19.” Last modified 2020. Accessed March 1, 2021. http://enblog.shincheonji.kr/2020/03/0228-letter-of-appeal-from-shincheonji.html.

Bitmez, Serdar. "Saudi Arabia Bans Locals from Umrah over Coronavrius.” Last modified 2020. Accessed February 25, 2021. https://www.aa.com.tr/en/middle-east/saudi-arabia-banslocals-from-umrah-over-coronavirus/1754648.

Brookings. “Are Covid-19 Limitations Inflaming Religious Tensions?” Last modified 2020. 
Accessed March 7, 2021. https://www.brookings.edu/blog/order-fromchaos/2020/04/13/are-covid-19-limitations-inflaming-religious-tensions/.

Center of Human Rights in Iran. "Coronavirus: Citing Crowded Prisons, Renowned Attorney Nasrin Sotoudeh's Husband Calls for Release of Political Prisoners.” Last modified 2020. Accessed March 1, 2021. https://iranhumanrights.org/2020/02/coronavirus-citingovercrowded-prisons-renowned-attorney-nasrin-sotoudehs-husband-calls-for-release-ofpolitical-prisoners/.

Chulov, Martin. "Saudi Arabia Closes Two Holiest Shrines to Foreigners as Corovirus Fears Grow.” Last modified 2020. Accessed February 25, 2021. https://www.theguardian.com/world/2020/feb/27/saudi-arabia-coronavirus-shrinespilgrims-hajj-bans.

Dein, Simon, Kate Loewenthal, Christopher Alan Lewis, and Kenneth I. Pargament. "COVID19, Mental Health And Religion: An Agenda For Future Research.” Mental Health, $\begin{array}{lllllll}\text { Religion } \quad \& \quad \text { Culture } & 23, & \text { no. } & 1 & \text { (2020): }\end{array}$ https://www.tandfonline.com/doi/pdf/10.1080/13674676.2020.1768725?needAccess=true.

Durham, Cole. "Freedom of Religion or Belief: Law Affecting the Structuring of Religious Communities." Organization for Security and Co-operation in Europe, 1999. https://www.osce.org/files/f/documents/4/7/16698.html.

Durham Jnr, Cole. "Religious Freedom in a Worldwide Setting: Comparative Reflections." In Speech Delivered at Political Academy of Social Sciences. Brigham University, 2011.

ELSAM. "Bupati Tasikmalaya Harus Lindungi Jamaah Ahmadiyah: Hentikan Penyegelan Mesjid, Dan Fokus Tangani Wabah Covid-19.” Last modified 2020. Accessed March 1, 2021. https://elsam.or.id/bupati-tasikmalaya-harus-lindungi-jamaah-ahmadiyah-hentikanpenyegelan-mesjid-dan-fokus-tangani-wabah-covid-19/.

European Commission For Democracy Through Law. "Guidelines For Legislative Reviews of Laws Affecting Religion Or Belief OSCE/ODIHR Panel Of Experts On Religion Or Belief.” Last modified 2004. Accessed February 27, 2021. https://www.venice.coe.int/webforms/documents/default.aspx?pdffile=CDL(2004)061-e.

Evans, Carolyn. Legal Protection of Religious Freedom in Australia. Australia: Federation Press, 2012.

Evans, Malcolm. "The Freedom of Religion or Belief in the European Court of Human Rights since the Kokkinakis Case Or 'Quoting Kokkinakis."' In The European Court of Human 
Rights and the Freedom of Religion or Belief, 33-54. Boston: Brill Nijhoff, 2019.

Habibi, Roojin, Steven J. Hoffman, and Gian Luca Burci. "The Stellenbosch Consensus on Legal National Responses to Public Health Risks, Clarifying Article 43 of the International Health Regulations." International Organizations Law Review (2020): 1-68. https://brill.com/view/journals/iolr/aop/article-10.1163-15723747-2020023/article10.1163-15723747-2020023.xml?language=en.

Hill QC, Mark. "Coronavirus and the Curtailment of Religious Liberty.” MDPI, Open Access Journal 9, no. 4 (2020): 1-19.

Hoshur, Shohret. "Residents of Xinjiang's Ghulja City Going Hungry Under Coronavirus Quarantine." Last modified 2020. Accessed March 1, 2021. https://www.rfa.org/english/news/uyghur/hungry-02242020153509.html.

Human Rights Watch. "Human Rights Dimensions of COVID 19 Response.” Last modified 2020. Accessed February 16, 2021. https://www.hrw.org/news/2020/03/19/human-rightsdimensions-covid-19-response.

Ibrahim, Johnny. Teori \& Metodologi Penelitian Hukum Normatif. Malang: Bayumedia, 2006. de La Ferriere, Alexis Artaud. "Coronavirus: How New Restrictions on Religious Liberty Vary Across Europe." Last modified 2020. Accessed February 25, 2021. https://theconversation.com/coronavirus-how-new-restrictions-on-religious-liberty-varyacross-europe-135879.

MacNaughton, Gillian. "Untangling Equality and Non-Discrimination to Promote the Right to Health Care for All." Health and Human Rights Journal 11, no. 2 (2009): 47-63.

Manchin, Gayle. “COVID-19 Symposium: Don't Let Religious Freedom Become a Casuality of Coronavirus, Opinio Juris." Last modified 2020. Accessed February 25, 2021. https://opiniojuris.org/2020/04/06/covid-19-symposium-dont-let-religious-freedombecome-a-casualty-of-coronavirus/.

Marshal, Paul. "Do Government Limitations on Larger Church Gathering Violate Religious Freedom?" Last modified 2020. Accessed March 15, 2021. https://providencemag.com/2020/03/government-limitations-larger-church-gatheringviolate-religious-freedom/.

Marzuki, Peter. Penelitian Hukum. Jakarta: Prenada Media Group, 2005.

Murdoch, Jim. Protecting the Right to Freedom of Thought, Conscience and Religion under the European Convention on Human Rights. Strasbourg: Council of Europe, 2012. 
https://www.echr.coe.int/LibraryDocs/Murdoch2012_EN.pdf.

Parliament of Australia. "Definition and Scope of the Right to Freedom of Religion or Belief." $\begin{array}{lllll}\text { Last } \quad \text { modified } 2019 . & \text { Accessed }\end{array}$ https://www.aph.gov.au/Parliamentary_Business/Committees/Joint/Foreign_Affairs_Defen ce_and_Trade/Freedomofreligion/Interim_Report/section?id=committees\%2Freportjnt\%2F 024110\%2F25177\#: :text=Religious freedom includes both the,be limited for any reason.\&tex.

Pelčić, Gordana, Silvana Karačić, and Galina L Mikirtichan. "Religious Exception for Vaccination or Religious Excuses for Avoiding Vaccination.” Croat Med J. 57 (2016): $516-521$. https://www.ncbi.nlm.nih.gov/pmc/articles/ PMC5141457/pdf/CroatMedJ_57_0516.pdf.

Petkoff, Peter. "Forum Internum and Forum Externum in Canon Law and Public International Law with a Particular Reference to the Jurisprudence of the European Court of Human Rights.” Religion and Human Rights 7, no. 3 (2012): 183-214.

Pierik, Roland. "On Religious and Secular Exemptions: A Case Study of Childhood Vaccination Waivers." Ethnicities. 17, no. 2 (2017): 2020-241. https://www.ncbi.nlm.nih.gov/pmc/articles/PMC5428064/pdf/10.1177_146879681769262 9.pdf.

Plessis, Georgia Alida Du. "COVID-19 and Limitations to the International Right to Freedom of Religion or Belief." Journal of Church and State csaa082 (2020).

Pompeo, Michael R. "United States Calls for Humanitarian Release of All Wrongfully Detained Americans in Iran, Press Statement.” Last modified 2020. Accessed March 1, 2021. https://www.state.gov/united-states-calls-for-humanitarian-release-of-all-wrongfullydetained-americans-in-iran/.

Qazi, Shereena, and Ashkar Thasleem. "Anguish as Sri Lanka Forces Muslims to Cremate COVID-19 Victims." Last modified 2020. Accessed March 5, 2021. https://www.aljazeera.com/news/2020/04/anguish-sri-lanka-forces-muslims-crematecovid-19-victims 200403053706048.html.

Rashid, Raphael. "Being Called a Cult Is One Thing, Being Blamed for an Epidemic Is Quite Another." Last modified 2020. Accessed March 1, 2021. https://www.nytimes.com/2020/03/09/opinion/coronavirus-south-korea-church.html.

Soekanto, Soerjono. Pengantar Penelitian Hukum. Jakarta: UI Press, 1986. 
Temperman, Jeroen. “Are State Churches Contrary to International Law?” Oxford Journal of Law and Religion 2, no. 1 (2013): 119-149.

The National News. "Indian Hospitals Shuns Muslims as Coronavirus Spurs Discrimination." Last modified 2020. Accessed March 1, 2021. https://www.thenationalnews.com/world/asia/indian-hospital-shuns-muslims-ascoronavirus-spurs-discrimination-1.1008876.

The U.S. Commission on International Religious Freedom. "USCIRF Troubled by Denial of Food Aid to Pakistani Hindus and Christians." Last modified 2020. Accessed March 5, 2021. https://www.uscirf.gov/news-room/releases-statements/uscirf-troubled-denial-foodaid-pakistani-hindus-and-christians.

UN Human Rights Committee. International Covenant on Civil and Political Rights, 2018.

United Nations Economic and Social Council. "The Right to the Highest Attainable Standard of Health (Article 12 of the International Covenant on Economic, Social and Cultural Rights).” Last modified 2020. Accessed March 10, 2021. https://tbinternet.ohchr.org/_layouts/15/treatybodyexternal/Download.aspx?symbolno=E/C $.12 / 2000 / 4 \&$ Lang=en.

United Nations Human Rights Office of the High Commissioner. "International Standards on Freedom of Religion or Belief." Accessed March 10, 2021. https://www.ohchr.org/EN/Issues/FreedomReligion/Pages/Standards.aspx.

United States Commission on International Religious Freedom. USCIRF Recommended Countries of Particular Concern, China, Annual Report, 2019.

World Health Organization. "Chapter 10: Controlling the Spread of Infectious Diseases, Advancing the Rights to Health: The Vital Role of Law." Last modified 2016. Accessed March 15, 2021. https://www.who.int/healthsystems/topics/health-law/chapter 10. pdf? ua $=1$.

—. "WHO Director-General's Opening Remarks at the Media Briefing on COVID-19." Last modified 2020. Accessed February 15, 2021. https://www.who.int/directorgeneral/speeches/detail/who-director-general-s-opening-remarks-at-the-media-briefing-oncovid-19---11-march-2020.

$\mathrm{Xu}$, Jianhua, Guyu Sun, and Wei Cao. "Stigma, Discrimination, and Hate Crimes in ChineseSpeaking World amid Covid-19 Pandemic.” Asian Journal of Criminology 16 (2021): 5174. https://link.springer.com/content/pdf/10.1007/s11417-020-09339-8.pdf. 
Yapp, Eugene. "Covid-19 and the Right to Freedom of Religion and Belief." Last modified 2020. Accessed February 27, 2021. http://shapesea.com/op-ed/covid-19/covid-19-and-theright-to-freedom-of-religion-and-belief/. 